\title{
The State of Internally Displaced Persons Camps in Nigeria: A Case Study of Durumi Camp in the Federal Capital Territory of Nigeria
}

\author{
Askederin, F. $\mathrm{M}^{1^{*}}$, Omole, D. $\mathrm{K}^{2}$, Shonibare. D. $\mathrm{O}^{2}$ \\ ${ }^{1}$ Department of Public Administration, Texila American University, Georgetown, Guyana \\ ${ }^{2}$ Nigerian Educational Research and Development Council, Sheda, Abuja, Nigeria
}

\begin{abstract}
This Investigation was conducted among a small group of IDP population living at the heart of Abuja, Federal Capital Territory, which is the capital city of Nigeria. The study was conducted to determine the living conditions of Internally Displaced Persons in the Camp and their access to basic amenities as action research. It was conducted through an unstructured interview of the sampled population in the Camp to source relevant information. Data was collected by taking notes and recording of interview sessions. Results revealed that 2830 individuals live in the camp, mostly in family units. IDPs in the camp come from the Northeast geopolitical zone of Nigeria in the states of Borno, Adamawa, and Yobe, with the majority of them from Borno state. They were all displaced as a result of insurgency. This IDP camp is organized with a leadership structure and defined system for the management of amenities such as the health clinic, water supply, allocation of shelter, and sharing of donated items received from philanthropists, the private sector, and other well-wishers. The camp has running water, a clinic for basic health care provision, a borehole, toilet facilities, a store for foodstuff and a security post within 500 metres to 1 kilometre of the Camp.
\end{abstract}

Keywords: Humanitarian, Internally Displaced Persons, Refugees.

\section{Introduction}

Abuja is the Federal Capital city of Nigeria and is located in the North Central Zone of the Country. Nigeria is considered the giant of Africa, with an estimated population of over 200 million individuals $[1,2]$. The country has been fighting Insurgency since 2009, and this has led to the displacement of citizens from the Northeastern States of Borno, Adamawa and Yobe, commonly referred to as BAY states [3]. As at the end of 2020, there were about 2.73 million people in Nigeria displaced by disasters majorly caused by insurgency and banditry [4]. This problem has caused a large-scale Humanitarian Crisis in the Country. Humanitarian crisis have become a serious challenge globally, with over 70 million people displaced worldwide as of January 2019 [5].
A Humanitarian Crisis are defined as a situation where there is an exceptional and widespread threat to life, health, or basic subsistence that is beyond the coping ability of individuals or communities [6]. This was seen in war-torn countries like Afghanistan Iraq, South Sudan, and Somalia but not witnessed at a large scale in Nigeria until recently. The country, therefore, had no prior framework or strategy put in place for dealing with this crisis. Communities affected had to rely on Aid coming from Development Partners and International Organizations to bring relief and meet their immediate needs. The absence of legal and institutional frameworks for the economic, social, and cultural rights of IDPs globally and in Nigeria, in particular, has specifically resulted in continuous disharmony among agencies tasked with catering for IDPs [7]. 
The concept of Insurgency emanating into the humanitarian crisis can be defined as a protracted political-military struggle directed toward subverting or displacing the legitimacy of a constituted government or occupying power and completely or partially controlling the resources of a territory through the use of irregular military forces and illegal political organizations [8]. This has become a global challenge with problems of insurgency caused by different groups in Afghanistan, Iraq, Syria, Libya, Somalia, and recently Nigeria. As earlier indicated, the problem in Nigeria is majorly caused by the Jama'atu Ahli es Sunna Lidda'swati wal-Jihad commonly known as Boko Haram. This has led to large-scale displacement, particularly in Borno State [9].

According to the UNHCR, "An Internally Displaced Person (IDP) or groups of persons are individuals who have been forced or obliged to flee or to leave their homes or places of habitual residence, in particular as a result of or in order to avoid the effects of armed conflict, situations of generalized violence, violations of human rights or natural or human-made disasters, but who have not crossed an internationally recognized State border" $[10,11]$.

This definition recognises IDPs as persons who are still within the borders of their own country but have left their homes due to some disaster or conflict. These two factors are important in distinguishing IDPs from other groups that move from one place to the other within a country [12]. The movement of IDPs from their homes or place of residence must be forced by Natural or Man-made Disasters, but these individuals have not crossed an Internationally recognized border which could be their country of citizenship or that of residence.

It is common for people to see Refugees and IDPs as the same and sometimes even interchange their definitions. It is, therefore, necessary to define refugees in this paper. The 1951 Refugee Convention is a key legal document and defines a refugee as "Someone who is unable or unwilling to return to their country of origin owing to a well-founded fear of being persecuted for reasons of race, religion, nationality, membership of a particular social group, or political opinion." Today, the Northeastern part of Nigeria has become the epicentre of insurgency in West Africa, leaving behind a population displaced from their community, and this is a problem that the Nigerian government is determined to resolve. IDPs have become widely spread across the country, seeking shelter in camps within the affected states of Borno, Adamawa, and Yobe, as well as other states across the Country [13].

Food insecurity, human casualty, and displacement are some of the most resounding humanitarian effects of Boko Haram insurgency in all the surveyed camps in the Northeastern states of Borno, Adamawa, and Yobe [14]. The situation of IDPs is not conducive, and the camps are overcrowded, and many of the IDP camps in Abuja lack basic amenities as expressed by a cross-section of the IDP population interviewed, and little or nothing has been done to address this by the state and/or federal governments [15]. This study revealed that IDPs interviewed in Abuja expressed their challenges to include the inability to secure a means of livelihood and essential services like shelter, food, health, and education services. For example, most IDPs claim their children had better education back in their communities than their current location in the IDP camps; in these camps, teachers are volunteers that come to teach only when they are free, and the syllabus are not standardized [15]. These IDPs explained that when they opt to put their children in community schools, they are charged higher fees because they are not indigenes of the FCT. This study sought to establish the current situation in IDP Camps with special reference to Durumi IDP Camp.

One of the essentials of livelihood is shelter since these people had to flee their homes. Some find accommodation with friends and family in locations considered to be safe, while others 
have to seek shelter in camps. Food is another major challenge for IDPs whom farmers are predominantly and have lost their access to land for farming and livestock raising. They are heavily dependent on food assistance [16]. Education facilities are commonly lacking, with few teaching structures and personnel in the camps. Additionally, many IDPs face health crisis like cholera, meningitis etc. due to poor living conditions, overcrowding, and poor access to hospitals. Security is another major issue due to random attacks still being carried out by the insurgent groups. It is against this background that the study was carried out to $\mathrm{x}$ ray the camping situation in Durumi IDP Camp to establish the current trend and for evidential documentation provision.

\section{Problem Statement}

Durumi IDP Camp is located in the heart of the Capital city of Nigeria, making it one of the biggest and busiest IDP Camps in the North Central part of the Country. It is one of the most visited Camps but do not enjoy some of the benefits received by IDP Camps in the Northeast States, which have the highest rates of Insurgency. For example, none of the United Nations bodies like the International Office on Migration (IOM), World Food Programme (WFP), and other International NGOs work in this location.

This is because their mandates are mostly to cover the North-Eastern states where insurgency continues to affect the citizen, continuously displacing people. The North Central region is particularly interesting in the sense that many IDPs live in the city but are not recognized or organized as done in the Northeast. This makes it more difficult for the IDPs like those in Durumi to demand for their rights and negotiate for benefits due to them.

Durumi IDP Camp has the largest number of IDPs in Abuja, and it is strategically located in the city center. Many of the IDPs that have graduated out of Camps in FCT lived in this Camp at one point or the other. Understanding and assessing the population and living conditions in this Camp will provide an insight to the situation of IDPs living in the North Central geopolitical zone in general and the Federal Capital Territory in particular.

\section{Research Objectives}

The main focus of this case study is to have a critical insight to the lives of IDPs living within the city capital and determine if they enjoy particular advantages as a result of their location.

The following are specific objectives:

1. To determine the location where the IDPs in Durumi Camp come from.

2. To estimate the population of IDPs in the camp.

3. To determine the causes of displacement for IDPs in Durumi Camp, Abuja.

4. To identify amenities that are available in the camp.

5. To determine the trade or employment opportunities available to IDPs in the camp.

\section{Research Question}

The following research questions are populated to sharpen the investigation.

1. Where do the IDPs living in Durumi Camp come from?

2. What is the population of IDPs in Durumi?

3. What are their causes of displacement?

4. Do the IDPs have access to basic amenities like shelter, water, food, education, health care, and Security?

5. Do the IDPs have access to employment opportunities?

\section{Significance of the Study}

The research is expected to provide information on the lives of Internally displaced persons living within the capital city. It will provide information on the services available or lacking for the IDPs in Durumi Camp, Abuja FCT. It will identify areas of support required by the IDPs in this location. 


\section{Research Method}

A case study entails detailed and intensive analysis of a single case and is concerned with the nature of the case in question $[17,18]$. This could be the study of a single community like Whyte's (1955) study of Cornerville in Boston [19], or a study of a single school like Burgess (1983) study of Beachside Comprehensive School [20]. The tool used for the interview was an interview schedule, which was applied through an in-depth discussion with a number of Internally Displaced Persons. Consent was received from all Internally Displaced Persons that participated in the study. The purpose and objective of the study was explained in English and the local language. Individuals' names were not recorded during data collection in effort to maximize confidentiality. Confidentiality was maintained by keeping details of all the interviews with the researcher, and no information collected from one IDP was shared with other IDPs.

This research used a qualitative method to study the population. There are six states in the North Central geopolitical zone of the Country, which are Benue, Nasarawa, Niger, Kogi, Kwara, Plateau, and the Federal Capital Territory (FCT). According to data collected from NEMA, the population of IDPs in the North Central geopolitical zone of Nigeria is 30,165 individuals living in 31 IDP camps in three states of the region. Based on the data received, Durumi IDP Camp has a population of 2740 Internally Displaced Persons. The Target Population for the study are IDPs living in the Durumi IDP camps in the North Central region of Nigeria.

Purposive sampling of individuals to be interviewed was carried out in consultation with the leadership of the Camp. The First level of engagement was with the Vice Chairman of the Camp as the current chairman was away. Individuals were selected for an in-depth interview with a conscious effort to ensure male, female, and youth are interviewed.
Data was collected onsite by the principal researcher, who interviewed the sampled individuals through face-to-face interaction. The interview was recorded on paper and audio, and it was completed within 14 to 20 minutes. The instrument used to collect data for the research was an unstructured questionnaire.

The research adopted an inductive research approach where data is collected from IDP camps and then analyzed in an attempt to develop a better understanding of the lives of Internally Displaced People living in camps within cosmopolitan areas. This approach is chosen because there are no clearly defined theories or understanding peculiar to this category of IDP.

Inductive analysis was deployed to determine important patterns and themes to confirm findings from the data collected. Data was analyzed using simple statistical tools to determine inter-relationships in responses.

\section{Results}

The results revealed the following, which have been carefully articulated under the research question that each provides an answer to:

1. Where do the IDPs living in Durumi Camp come from?

2. What is the population of IDPs in Durumi?

3. What are their causes of displacement?

4. Do the IDPs have access to basic amenities like shelter, water, food, education, health care, and Security?

5. Do the IDPs have access to employment opportunities?

A total of 18 Internally Displaced Persons were interviewed in Durumi IDP Camp of the FCT during data collection on the field. Engagement with the Camp leadership revealed that individuals living at the camp come from the Northeastern Geopolitical zone states of Borno, Adamawa, and Yobe. These individuals are from various Local Government Areas (LGA) of the three states. Data collected in the Durumi IDP camp indicated that a total of 2830 individuals 
are living in the camp. This shows a $96.81 \%$ accuracy when compared with data collected from NEMA. All the IDPs where displaced as a result of the Boko Haram Insurgency.

The displacement has resulted in hardship for the individuals living in this Camp as well as their families. Basic services like Shelter, Food, Water, Sanitation, Hygiene, Health, Education, and Security services are no longer sufficient to the individual and his/her family even when they are made available.

The Shelter is one of the basic facilities required by a displaced person. IDPs in this camp set up tents in open spaces. The Camp management allocates space for the new IDP, and then, the IDP makes tents from Sticks and Polythene materials. The sourcing of materials and setup are left entirely to the individuals, and there is no government involvement in the structuring of accommodation for the IDPs. The number of IDPs that sleep in a unit of shelter varies but was generally said to be between 8 to 14 individuals, with the majority living in family units.

The case study analysed how IDPs access food within or around the camps? In the Durumi Camp, most IDPs access food from well-wishers or donors. They supplement this food source with what they buy from the market. Most of what IDPs receive from donors are grains and legumes, while they supplement with other food items in the categories of proteins, vegetables, minerals, and oils required to make a meal.

The camp has a reliable water source through a borehole that was funded by a philanthropist. Water, sanitation, and hygiene facilities were all visible in the Durumi IDP Camp, and these are some of the basic services required for survival by an individual. The Camp has toilet facilities with Water Closet (WC), and the men and women have different toilets. There is a sanitation schedule available at the IDP Camp, and general cleaning is done once in a month.

There is a health facility constructed by a Non-governmental Organisation in the Durumi Camp, a nurse is a resident every day during working hours, while a doctor comes twice a week. Immunization services are offered once a week. When an ailment becomes complicated, the clinic refers an IDP to the nearby General Hospital. Drugs available at the clinic are provided free of charge, however, the IDPs are given a prescription pad to buy some drugs outside when a particular medication required by the IDP is not available.

Data collected from the research shows that IDPs in Durumi camp live within family structures and have dependents that are school age. Interview of the IDPs with children reveals that about $51 \%$ of them send their children to a nearby Government school as there are no primary schools within the camp. Feedback from those interviewed indicates that none of the IDPs send their children to Private school, even those that go to public schools complain of hidden fees that are collected from the children, such as Parent Teachers Association (PTA) levies.

Employment provides an individual with a source of income that can be used to carter for himself/herself and the family. It helps to reduce the vulnerability of an Internally Displaced Person and provide them with a means to support their family. Data collected from the Durumi Camp reveals that the majority of the IDPs are engaged in part-time employment such as driving, tailoring, carpentry, plumbing. A Nongovernmental organization has set up a skill acquisition programme in the Camp, and they train the women and men in various crafts.

Internally Displaced Persons in the Durumi IDP Camp indicated satisfaction with the security within their Camps. They made a comparison with the security condition in their communities in Borno, Adamawa, and Yobe, saying that they feel much safer here than when they were in their communities. There is a security post within 500metres of the Camp, and security personnel are always present at the post.

\section{Discussion}

The Durumi IDP Camp in the Federal Capital Territory was the Case Study for this research. 
This Camp is situated at the heart of the city, about $10 \mathrm{~km}$ from the Central Business District. Data collected revealed that the majority of IDPs in the Camp come from Borno, Adamawa, and Yobe States, which are in the Northeast Geopolitical Zone of Nigeria. This is a common phenomenon for IDPs across the world, as many of them travel several kilometers to escape their homes in times of disasters such as insecurity, banditry, or natural disasters like flooding [11].

The Boko Haram Insurgency/Insecurity is the cause of displacement among the Internally Displaced Persons interviewed as indicated by all individuals interviewed in the Durumi IDP Camp, who stated it as their reason for displacement. Similar findings were seen in the research of IDPs by [15] in 2019. This reason is closely followed by Banditry and Kidnapping as this cause of displacement is closely becoming a sauce of major concern as, indicated in studies conducted by [21].

Data collected from the Camp leadership reveals that about 2830 individuals live in the Camp, and over $50 \%$ of them have dependents. Basic services like shelter, water, food, health, and education services were available at and around the Camp, but its sufficiency varies depending on the service. While water is generally available as there is a borehole within the facility, food is not enough, and often times the IDPs need to supplement their food source. The Clinic within the Camp carter to most of their primary needs, but the IDPs are still challenged when referred to the General hospitals for an ailment that cannot be addressed at the Camp Clinic. This is because they have to pay fees at the General Hospital, and sometimes the cost is not what they can afford. More than $50 \%$ of IDPs have school-aged Children, and they send their children to a nearby government school.

These data show that IDPs have received some level of support from well-wishers, Philanthropist, Non-governmental organizations in the areas of Water, food, health care, and education. They also have some level of support from Government in terms of access to Public Health Facilities and Educational services in the community.

The Shelter is made from sticks and polythene bags which is common across most IDP camps within and outside Nigeria. Most IDPs in the Durumi IDP Camp indicated that they were farmers back in their communities before displacement. However, because they have no access to land, most of them have to engage in other trades such as driving, tailoring, etc.

Security is a major challenge across the Country, but IDPs indicate that there is better security at the Camp than in their original homes. Data collected reveals that security is provided by the government through the Police.

\section{Conclusion and Recommendations}

In conclusion, this study reveals that there is a large number of Internally Displaced Persons living in Durumi Camp of the Federal Capital City Abuja. They all come from the Northeast Geopolitical Zone from the states of Borno, Adamawa, and Yobe. Most IDPs have found some form of daily income job which they are engaged in, which include Motorcycle riding, tailoring, farming, labouring.

The major finding is that they have enjoyed the advantage of living within the city as they have access to many daily income jobs from construction jobs happening within the city. They have access to several donations which come from Philanthropists, NGOs, Private Individuals as it is often the most visited IDP Camp due to its accessibility.

Considering the opportunities available in the Federal Capital Territory and the way IDPs in this Camp have become familiar with the environment, it will go a long way if these 2830 IDPs can be settled through government housing projects around the city.

\section{Acknowledgement}

I wish to thank God Almighty for making this research possible. I wish to thank my professors for their support in my Research. I extend my 
sincere thanks to the Government Agencies and Departments that provided information that supported this research.

Finally, I wish to extend my sincere gratitude to the leaders and population of the Durumi IDP Camp in the FCT for their time in providing information that made this research possible. They were instrumental in the conduct of this research.

\section{Reference}

[1] National Population Commission, 2016, Date of access:

05-10-2020.

https://www.worldometers.info/world-

population/nigeria-population/.

[2] UNFPA, 2020, World Population Dashboard, Date of access: 10-06-2021. https://www.unfpa.org/data/world-population/NG.

[3] UNOCHA, 2020, Nigeria: Humanitarian Response Plan, Date of access: 02-10-2020. https://www.humanitarianresponse.info/en/operation s/nigeria/humanitarian-response-plan.

[4] IDMC Report, 2021, Date of access: 31-03-2021. https://www.internal-displacement.org/global-

report/grid2021/.

[5] Norwegian Refugee Council, 2020, Report on 70.8-million-displaced-people, Date of access: 3103-2021. https://www.nrc.no/shorthand/fr/70.8million-displaced-people/index.html.

[6] Macrae, J., and Harmer, A., 2003, Humanitarian Action and the Global War on Terror: A Review of Trends and Issues (HPG Report 14, London: ODL).

[7] Kolawole, A., 2013, Towards the evolution of legal and institutional framework for the protection of internally displaced persons (IDPs) in Nigeria, Ontario International Development Agency. ISSN 1923-6654.

[8] US Guide, 2020, Guide to the Analysis of Insurgency, Date of access: 27-09-2020. https://www.hsdl.org/?view\&did=713599.

[9] IDMC Report, 2018, Date access: 03-04-2021. https://www.internaldisplacement.org/features/nigeri a-internal-displacement-crisis-conflict-floods.

[10] UNHCR, 2019, Nigeria Key Message update, September 2019, Date of access: 05-10-2020.

\section{Conflict of Interest}

This research was carried out by the author using personal time and resources. The research was not sponsored by any individual, group, or organization. There is no conflict of interest in this research.

https://reliefweb.int/report/nigeria/nigeria-keymessage-update-september-2019.

[11] United Nations Commission on Human Rights, Analytical Report of the Secretary-General on Internally Displaced Persons, UN Doc. E/CN.4/1992/23 (14 February 1992), para. 17.

[12] United Nations Commission on Human Rights, 1998, Report of the Representative of the SecretaryGeneral on Internally Displaced Persons: Guiding Principles on Internal Displacement, UN doc. E/CN.4/1998/53/Add.2 (11 February 1998).

[13]NCFRMI, 2019, Persons of Concern Report, Date of accessed: 27-04-2020. https://ncfrmi.gov.ng/. [14] Imasuen, E., 2015, Insurgency and the humanitarian crises in the Northern Nigeria: The case of Boko Haram, African Journal of Political Science, and International Relations, 9(7), $284-296$.

[15] Olanrewaju, F. A., Olanrewaju, A., Omotoso, F., Alabi, J. O., Amoo, E., Loromeke, E., and Ajayi, L.A., 2019, Insurgency and the Invisible Displaced Population in Nigeria: A situational Analysis, SAGE, DOI: $10.1177 / 2158244019846207$.

[16] Mooney, E., 2005, Refugee Survey Quarterly, 24(3), Date of access: 10-04-2021. https://doc.rero.ch/record/299905/files/hdi049.pdf.

[17]Bryman, A., 2008, Social research methods (Oxford, U.K.: Oxford University Press).

[18] Stake, R. E., 1995, The Art of Case Study Research (Thousand Oaks, CA: Sage).

[19] Whyte, W. F., 1995, Street Corner Society 2nd edn (Chicago: University of Chicago Press).

[20] Burgess, R. G., 1983, Inside Comprehensive Education: A study of Bishop McGregor School (London, U.K: Methuen). 
[21] Okoli, C. A., 2019, What can be done to fight Rural Banditry in Nigeria. Date of access: 05-03-
2021. https://reliefweb.int/report/nigeria/what-canbe-done-fight-rural-banditry-northern-nigeria. 